\title{
Adult polycystic kidney disease
}

Adult polycystic kidney disease (APKD), inherited as an autosomal dominant, has a birth incidence of nearly 1 in 1000 and an apparent mutation rate of 6.5 to $10 \times 10^{-5} .^{1}$ In Britain it is second only to familial hypercholesterolaemia (FH) in frequency and shares with $\mathrm{FH}$ the distinction of being an important Mendelian paradigm, study of which is likely to help clarify the aetiology of common and heterogeneous groups of diseases with variable severity. Indeed it is estimated that $10 \%$ of all end stage renal failure can be attributed to APKD although there is a wide range of ages of onset and great variation in severity. While the majority of people with the APKD gene will have developed kidney failure by the sixth decade, the frequency of polycystic kidney disease in randomly selected necropsies is considerably greater than the clinical prevalence rates. ${ }^{2}$ There are also well documented instances of infantile presentation in APKD families (reviewed by Kääriäinen ${ }^{3}$ on page 474 of this issue). Unlike $\mathrm{FH}$, in which the sex of the carrier and dietary factors are known to influence age of onset, it is not clear what determines the rate of cyst formation in APKD although the onset of symptoms may be attributable to complications (infection, hypertension, and kidney failure). APKD is a multisystem disease affecting typically the kidney and liver, but is also associated with intracranial arterial berry aneurysm and the risk of haemorrhage. The basic defect is unknown and recombinant DNA studies have once more proved their value in mapping a major gene in the absence of any biochemical clues, and may well lead at last to an understanding of the mysterious link between gene mutation and cystic abnormality.

In 1986 Reeders and colleagues ${ }^{4}$ showed genetic linkage between APKD and a hypervariable sequence ( $3^{\prime}$ HVR) about $8 \mathrm{~kb}$ from the $\alpha$ globin gene cluster. This allowed APKD to be assigned to chromosome 16 , the molecular genetics of which are reviewed by Sutherland $e a^{5}$ on page 451 . In the nine families studied by Reeders et al a maximum lod score (Z) of 25.85 at a recombination fraction 0.05 was reported. Subsequently, Reeders $e t$ at $t^{t}$ published details of a polymorphism of phosphoglycolate phosphatase (PGP) which was found to be closely linked to APKD (maximum lod score $(Z) 11 \cdot 61$, recombination fraction=0) and the $\alpha$ globin cluster $\left(Z=8 \cdot 21\right.$, recombination fraction=0). Watson et al ${ }^{7}$ on page 457 provide further data on the linkage between APKD and PGP.

Lazarou et $a l^{8}$ on page 466 have now extended this work by studying 13 South Wales kindreds using kaplotypes derived from restriction fragment length polymorphisms (RFLP) revealed by enzyme RsaI in the $\alpha$ globin gene, and the polyallelic $P v u$ II polymorphism of the 3'HVR probe. Using the $\alpha$ globin and 3'HVR probes and constructing RFLP haplotypes, the system is remarkably polymorphic with $96 \%$ of subjects in the families being informative.

The study of Lazarou et al and the paper by Ryynanen et al $l^{\prime}$ on page 462 are consistent with a single locus for APKD in all the families studied, including apparently the remarkably benign and symptomless variety reported from Finland by Ryynanen $e t$ al. This is not to say that all adult polycystic kidney disease is due to one locus. The medullary type (McKusick 17400) and adult polycystic kidney disease with orofaciodigital syndrome type $\mathrm{I}^{10}$ are phenotypically and presumably genetically distinct. Similarly most cases of congenital or infantile polycystic disease are not associated with a family history of adult disease.

Reeders et $a l^{11}$ have already used the $3^{\prime} \mathrm{HVR}$ probe for prenatal diagnosis and limitations due to a possible recombination frequency of 0.03 to 0.05 will soon be overcome if the hot pursuit of flanking probes and of the APKD gene itself are successful. It is likely that virtually all subjects and pregnancies at risk will be informative before too long. However, preliminary experience in Manchester suggests an ambivalent attitude of families to prenatal diagnosis for APKD. This is because some relatives at risk perceive the management of APKD as being acceptable, no doubt in part because of the support available from the genetic register staff who collaborate with the renal unit to offer expert ultrasound examination at 18 and 20 years to those at risk. Annual review thereafter of those found to be positive hopefully will allow early treatment of infection and of hypertension and optimum timing for renal allografts before the vascular system has been irretrievably damaged by uncontrolled hypertension.

Undoubtedly some young adults shown to be carriers will prefer prenatal diagnosis and this will usually have been conditioned by close observation of a relative with end stage renal failure. For such persons, 
DNA prediction is complementary to ultrasound screening for carrier detection, but has the added advantage of not being age dependent. The immediate future will undoubtedly provide probes almost frees from recombination and even greater informativeness allowing precise prediction and prenatal diagnosis ing most families. But, in addition, as with all recently mapped genes, the aim is to sequence the gene, identify을 its product, hopefully understand the pathogenesis, and then perhaps design specific treatment.

\section{RODNEY HARRIS్}

\section{References}

' Dalgaard OZ. Bilateral polycystic kidney disease of the kidneys. Acta Med Scand (Suppl) 1957;158:1-251.

2 Torres VE, Holley KE, Offord KP. General features of autosomal dominant polycystic kidney disease. A. Epidemiology. In: Grantham JJ, Gardner KD, eds. Problems in diagnosis and management of polycystic kidney disease. Kansas City: PKR Foundation, 1985:49-69.

${ }^{3}$ Kääriäinen H. Polycystic kidney disease in children: a genetic and epidemiological study of 82 Finnish patients. J Med Genet 1987;24:474-81.

4 Reeders ST, Breuning MH, Davies KE, et al. A highly polymorphic DNA marker linked to adult polycystic kidney disease on chromosome 16. Nature 1985;317:542-4.

5 Sutherland GR, Reeders S, Hyland VJ, Callen DF, Fratini A. Mulley JC. Molecular genetics of human chromosome 16. J Med Genet 1987;24:451-6.

${ }^{6}$ Reeders ST, Breuning MH, Corney G, et al. Two genetic markers closely linked to adult polycystic kidney disease on $\overrightarrow{0}$ chromosome 16. Br Med J 1986;292:851-3.

7 Watson ML, Wright AF, MacNicol AM, et al. Studies of genetioc linkage between adult polycystic kidney disease and three markers on chromosome 16. J Med Genet 1987;24:457-61.

${ }^{8}$ Lazarou LP, Davies M, Sarfarazi M, et al. Adult polycysti६o kidney disease and linked RFLPs at the $\alpha$ globin locus: a genetion study in the South Wales population. J Med Genet 1987;24: 466-73.

9 Ryynanen M, Dolata MA, Lampainen E, Reeders ST. Localisa $-\vec{f}$ tion of a mutation producing autosomal dominant polycystic ${ }^{6}$ kidney disease without renal failure. J Med Genet 1987;24:음 $462-5$.

11 Donnai D, Kerzen-Storrar L, Harris R. Familial orofaciodigita $\vec{b}$ syndrome type I presenting as adult polycystic kidney disease. Med Genet 1987;24:84-7.

1 Reeders ST, Gal A. Propping P, et al. Prenatal diagnosis of autosomal dominant polycystic kidney disease with a DNA probe. Lancet 1986;ii:6-8. 